\title{
Feasibility and efficacy of surgical staging for endometrial cancer by using Pfannenstiel incision
}

\author{
Wykonalność i skuteczność chirurgicznej oceny stopnia zaawansowania \\ raka endometrium z zastosowaniem nacięcia Pfannenstiela
}

\author{
${ }^{1}$ Department of Surgical Oncology, South Egypt Cancer Institute, Assiut University, Egypt \\ 2 Department of General surgery, Faculty of Medicine, Assiut University, Egypt \\ 3 Department of Obstetrics and Gynecology, Faculty of Medicine, Assiut University, Egypt \\ Correspondence: Mohamed I. Omar, Surgical Oncology Department, South Egypt Cancer Institute, Assiut University, 10 Elmethaq Street, Manshiet Elomraa, Assiut - Assiut - Egypt, \\ e-mail: mohesomar@aun.edu.eg; secondary e-mail: mo7esomar@gmail.com; ORCID ID: https://orcid.org/0000-0003-0921-7700; mobile: 00201063302315, home phone: +20-88-2373460
}

\begin{abstract}
Objective: The purpose of this study was to evaluate short-term oncological and perioperative outcomes of using Pfannenstiel incision for the surgical staging of endometrial carcinoma. Methods: This was a retrospective cohort study. All patients with endometrial carcinoma referred to the Department of Surgical Oncology, South Egypt Cancer Institute, for surgical staging between January 1, 2014, and July 1, 2016, were enrolled. The patients were grouped according to the type of surgical incision either through Pfannenstiel incision or midline incision, and the groups were compared. Demographic, clinical, operative, and short-term oncological features were analyzed. Results: A total number of 117 patients were recruited, of which 45 patients had Pfannenstiel incision, and 72 patients had midline incision. The clinical and pathological features of patients in both groups were similar. The operative outcomes showed no significant difference between the groups $(p>0.1)$. Postoperatively, the Pfannenstiel incision group had a statistically significant lower rate of complications compared to the midline incision group $(15.5 \%$ vs. $38.9 \%, p=0.02)$. The short-term oncological outcomes in the form of total procured lymph nodes or para-aortic lymph nodes were not statistically different $(p>0.1)$. Conclusion: Pfannenstiel incision can be safely performed for the surgical staging of endometrial cancer with acceptable oncological outcomes compared to the midline incision.
\end{abstract}

Keywords: endometrial cancer, staging, Pfannenstiel incision

Streszczenie Cel pracy: Celem pracy była analiza krótkoterminowych wyników onkologicznych i okołooperacyjnych chirurgicznej oceny zaawansowania raka endometrium z otwarcia sposobem Pfannenstiela. Metody: Do retrospektywnego badania kohortowego włączono wszystkie pacjentki z rakiem endometrium skierowane w okresie od 1 stycznia 2014 do 1 lipca 2016 roku do Kliniki Chirurgii Onkologicznej w Południowoegipskim Instytucie Onkologii (South Egypt Cancer Institute) w celu dokonania chirurgicznej oceny stopnia zaawansowania. Pacjentki pogrupowano według rodzaju wykonanego nacięcia (nacięcie Pfannenstiela lub nacięcie w linii środkowej), a następnie przeprowadzono porównanie grup. Analizie poddano charakterystykę demograficzną pacjentek, a także wyniki kliniczne i operacyjne oraz krótkoterminowe wyniki onkologiczne. Wyniki: Do badania włączono ogółem 117 pacjentek. U 45 z nich wykonano nacięcie Pfannenstiela, a u 72 nacięcie w linii środkowej. Cechy kliniczne i patologiczne były zbliżone w obu grupach. Pod względem wyników operacyjnych nie stwierdzono istotnej różnicy pomiędzy grupami $(p>0,1)$. Po przeprowadzonym zabiegu w grupie z nacięciem Pfannenstiela odnotowano statystycznie istotny niższy odsetek powikłań w porównaniu z grupą z nacięciem pośrodkowym (15,5\% vs $38,9 \%, p=0,02)$. Krótkoterminowe wyniki onkologiczne w postaci wszystkich pozyskanych węzłów chłonnych lub okołoaortalnych nie różniły się w sposób statystycznie istotny $(p>0,1)$. Wnioski: Porównanie obu rodzajów nacięcia wskazuje, że nacięcie Pfannenstiela może być bezpiecznie wykonywane w celu przeprowadzenia chirurgicznej oceny stopnia zaawansowania raka endometrium, zapewniając zadowalające wyniki onkologiczne.

Słowa kluczowe: rak endometrium, stopień zaawansowania, nacięcie Pfannenstiela 


\section{INTRODUCTION}

$\mathrm{E}$ ndometrial cancer is the most common gynecologic cancer in developed countries and the second most common gynecologic cancer worldwide ${ }^{(1)}$. Most endometrial cancers are diagnosed with early-stage/uterusconfined disease, and are usually cured by surgery alone. The management of endometrial carcinoma has progressed from an era of clinical staging in the 1970s to the presentw times of primary comprehensive surgical staging. The standard surgical procedure includes obtaining peritoneal wash for cytology, exploring the abdomen and pelvis, biopsy/excision of suspicious extra-uterine lesions, total hysterectomy with bilateral salpingo-oophorectomy, and retroperitoneal (pelvic + /- para-aortic) lymphadenectomy ${ }^{(2,3)}$.

The indications, extent, and therapeutic impact of lymphadenectomy remain controversial. Currently, systematic pelvic and para-aortic lymphadenectomy is the only way to accurately identify the presence of nodal disease in women with endometrial cancer. It is also useful for providing valuable prognostic data and for determining the need for adjuvant therapy ${ }^{(4-6)}$.

Surgical approaches aiming at limiting morbidity and improving the quality of life without affecting cure rates are being investigated. These comprise open and minimally-invasive approaches, with the former including midline incision (MLI) and Pfannenstiel incision (PFI). In our study, we aim to explore the favorable outcomes associated with the use of PFI in staging endometrial cancer patients, as compared to MLI.

\section{MATERIALS AND METHODS}

This was a retrospective cohort study which included all patients who underwent total abdominal hysterectomy for endometrial carcinoma between January 1, 2014, and July 1, 2016. The study was approved by the IRB under registration no. 0058-19. Data were retrospectively collected from patients' files in the Department of Surgical Oncology at South Egypt Cancer Institute. Patients who had not had lymphadenectomy, as well as those with an undocumented type of incision, were excluded from the analysis. Written informed consent was obtained from all participants, keeping personal data in confidentiality.

Diagnostic work-up included full history, physical examination including careful vaginal examination, and DRE along with routine laboratory parameters checked for all patients and baseline CA-125 level determined for most patients. Dilatation and curettage with biopsy for histopathologic examination were implemented in all cases. Metastatic work-up was tailored according to clinical circumstances.

\section{Surgical technique}

The surgical procedure consisted of exploratory laparotomy, peritoneal pelvic lavage for cytology, total abdominal hysterectomy, bilateral salpingo-oophorectomy, bilateral pelvic lymphadenectomy with para-aortic lymph nodes in most patients, and omental biopsy. The boundaries for pelvic lymphadenectomy extended from the mid-portion of the common iliac artery to the circumflex iliac vein, and from the genitofemoral nerve on the psoas muscle laterally to the ureter medially to include the internal iliac artery and vein and the obturator fossa anterior to the obturator nerve. When performed, para-aortic lymphadenectomy included removal of the nodal tissue up to the level of the inferior mesenteric artery.

The type of skin incision, either vertical MLI or PFI, was selected according to the preference of the attending surgeon. For patients with a prior MLI, the site of the previous scar was employed. Abdominal retractors were used for performing hysterectomy and the staging procedure in all patients.

\section{Data collection and patient grouping}

Data concerning patient demographics, stage of cancer, histology, grade, estimated blood loss, incision type, length of hospital stay, number and status of lymph nodes, and perioperative complications (including ileus, pneumonia, wound complications, and thromboembolic events), were collected retrospectively.

The patients were grouped according to the type of laparotomy incision into two groups:

- group 1: patients who underwent hysterectomy through PFI;

- group 2: patients who underwent hysterectomy through MLI.

\section{Statistical analysis}

Categorical variables were analyzed using the chi-square test, while continuous variables were compared using the Student's $t$-test. Data were expressed as number and $\%$ for qualitative variables, and mean \pm standard deviation for quantitative ones. For all statistical tests done, the threshold of significance was set at 5\% (two-tailed unless otherwise specified). All analyses were performed using the IBM SPSS Statistics ver. 24.0 (IBM Co., USA).

\section{RESULTS}

This study included a total of 117 consecutive patients who underwent surgery for the comprehensive staging of endometrial carcinoma between January 1, 2014, and July 1, 2016 in the Department of Surgical Oncology at South Egypt Cancer Institute. The 45 patients who had PFI were compared with the remaining time-matched 72 patients who had MLI.

The clinicopathological features of patients who underwent PFI and MLI were similar with respect to their age, body mass index, medical comorbidities, prior abdominal surgery, final histology, and tumor grade (Tab. 1). 


\begin{tabular}{|c|c|c|c|c|}
\hline \multicolumn{2}{|l|}{ Characteristics } & PFI (45) & MLI (72) & $p$ value \\
\hline \multicolumn{2}{|l|}{ Age } & $63.18 \pm 11.8$ & $61.13 \pm 11.7$ & 0.56 \\
\hline \multicolumn{2}{|l|}{ Body mass index } & $28.85 \pm 7.1$ & $28.75 \pm 6.4$ & 0.94 \\
\hline \multicolumn{2}{|l|}{ Diabetes mellitus } & $18(25 \%)$ & $9(20 \%)$ & 0.35 \\
\hline \multicolumn{2}{|l|}{ Hypertension } & $11(24.4 \%)$ & $14(19.4 \%)$ & 0.34 \\
\hline \multicolumn{2}{|l|}{ Other comorbidity } & $3(6.7 \%)$ & $8(11.1 \%)$ & 0.32 \\
\hline \multicolumn{2}{|c|}{ Previous laparotomy } & $12(26.8 \%)$ & $19(26.4 \%)$ & 0.29 \\
\hline \multirow[t]{2}{*}{ Histopathology } & Endometrioid & $29(64.4 \%)$ & $48(66.6 \%)$ & \multirow{2}{*}{0.15} \\
\hline & 0thers & $16(35.6 \%)$ & $24(33.3 \%)$ & \\
\hline \multirow[t]{2}{*}{ Tumor grade } & $\mathrm{G} 1-\mathrm{G} 2$ & $22(75.8 \%)$ & $35(72.9 \%)$ & \multirow{2}{*}{0.19} \\
\hline & G3 & $7(24.2 \%)$ & $13(27.08 \%)$ & \\
\hline
\end{tabular}

Tab. 1. Demographic and clinical parameters

The operative outcomes between the two groups showed no significant difference in terms of estimated blood loss, intraoperative complications or operative times between the groups $(p>0.05)$, postoperatively, and the overall complication rate was $29.9 \%$. The PFI group had a statistically significant lower rate of complications compared to the patients in the MLI group ( $15.5 \%$ vs. $38.9 \%, p=0.02)$. This was higher in terms of wound complications and pneumonia but especially pronounced in postoperative ileus $(p=0.03)$. The length of hospital stay was significantly shorter in the PFI group than in the MLI group (5.02 vs. 6.14 , respectively, $p \leq 0.001$ ).

The mean number of total retrieved lymph nodes was not statistically different between the two groups (20.2 vs. 21.51 , respectively, $p=0.16$ ) (Tab. 2). Moreover, the mean number of retrieved para-aortic LNs was similar between the two groups ( 5.02 vs. $5.71, p=0.79$ ). There were no operative or hospital deaths among the study groups.

\section{DISCUSSION}

Endometrial cancer is a highly treatable disease if diagnosed early. Extra-fascial hysterectomy with bilateral salpingo-oophorectomy along with comprehensive surgical staging including pelvic and para-aortic lymphadenectomy (except in low-risk disease) and peritoneal wash cytology remains the mainstay of surgical treatment of endometrial carcinoma. Currently, there is overall agreement that lymphadenectomy yields important prognostic information, however, there is still debate regarding the extent of lymphadenectomy, and whether or not it provides a therapeutic benefit or survival advantage ${ }^{(4-6)}$.

Different types of abdominal incisions exist, with the most commonly employed in gynecologic surgery being PFIs and MLIs. The choice of incision in cases of gynecologic malignancies is dependent on many factors including the BMI, planned surgical procedure, extra-uterine tumor spread, patient choice, and surgeon preference ${ }^{(7,8)}$. Midline incision is the preferred option by most surgeons, as it was traditionally advocated to give the best exposure and access to the abdominal cavity and pelvis. That is not based on solid evidence ${ }^{(9)}$. On the other hand, transverse incisions may provide some advantages regarding the early post-operative outcomes. Some authors reported less early postoperative pain and pulmonary and wound complications ${ }^{(10)}$. Others, however, reported no significant differences between the two types of incisions ${ }^{(11,12)}$. In gynecologic oncology, the feasibility and outcomes of using PFI in staging different types of genital tract

\begin{tabular}{|c|c|c|c|}
\hline Characteristics & $\operatorname{PFI}(45)$ & MLI (72) & $p$ value \\
\hline Estimated blood loss & $353.56 \pm 297$ & $365.73 \pm 275$ & 0.26 \\
\hline Operative time & $213.37 \pm 83$ & $202.18 \pm 53$ & 0.17 \\
\hline Hemoglobin shift & $1.6 \pm 1.52$ & $2.3 \pm 1.42$ & 0.01 \\
\hline Intraoperative complications & 0 & 0 & \\
\hline Overall postoperative complications & $7(15.5 \%)$ & $28(38.9 \%)$ & 0.02 \\
\hline Ileus & $2(4.44 \%)$ & $11(15.3 \%)$ & 0.037 \\
\hline Pneumonia & $2(4.44 \%)$ & $4(5.6 \%)$ & 0.32 \\
\hline Wound complications & $4(8.9 \%)$ & $13(18 \%)$ & 0.07 \\
\hline Thromboembolic events & $2(4.44 \%)$ & $3(4.2 \%)$ & 0.64 \\
\hline Total number of retrieved nodes & $20.2 \pm 7.1$ & $21.51 \pm 9.2$ & 0.16 \\
\hline Number of para-aortic nodes & $5.04 \pm 1.8$ & $5.71 \pm 1.8$ & 0.79 \\
\hline Length of stay & $5.02 \pm 2.68$ & $6.14 \pm 4.02$ & 0.001 \\
\hline Hospital death & 0 & 0 & \\
\hline
\end{tabular}


malignancies has been explored in few studies ${ }^{(7-9,13)}$. Pfannenstiel incision was found to offer an alternative approach to MLI, with comparable morbidity and mortality outcomes. Access to the abdomen and pelvis for optimal resection of disease together with sound oncological outcomes were not jeopardized by utilizing Pfannenstiel.

In our study, PFI was found to be associated with less overall postoperative complications than MLI, and lower postoperative incidence of pneumonia, thromboembolism, wound complications, and ileus. However, these observations did not reach statistical significance except for postoperative ileus. The low incidence of pneumonia, ileus and thromboembolism can be explained by early ambulation and less pain associated with PFI. These results are consistent with many literature reports ${ }^{(9,13)}$.

In our study, one of the major advantages of PFI was short hospital stay $(5.02 \pm 2.68$ days for PFI vs. $6.14 \pm 4.02$ for MLI, $p=0.001)$. This is in accordance with other reports ${ }^{(8,9,13)}$; Orr et al. reported that patients in the PFI group had a significantly shorter hospital stay than those with either vertical or Maylard incisions $(p<0.001)^{(13)}$. Moreover, Horowitz et al. reported that the median length of stay in hospital was statistically shorter after PFI than after MLI (3.0 vs. 4.0 days, $p=0.007)^{(9)}$. On the other hand, Ayhan et al. reported no significant differences with respect to mean hospitalization among the groups (mean duration of hospital stay $=6.3$ days $)^{(14)}$.

The mean estimated blood loss in the PFI group was comparable to that in the MLI group ( $353 \mathrm{cc}$ vs. $365 \mathrm{cc}, p=0.26$ ). However, hemoglobin drop was less in the PFI group than in the MLI group $(p=0.01)$. Some authors described less estimated blood loss with the PFI. Orr et al. reported that the estimated blood loss in the Pfannenstiel group (691 $\pm 66)$ was less than in the midline group $(1161 \pm 71)^{(13)}$. Ayhan et al. also reported a significant hemoglobin level shift which was more pronounced in the MLI group compared with the Pfannenstiel group ${ }^{(14)}$.

Regarding pelvic and para-aortic lymph node dissection, we found no statistically significant difference in lymph node yield between both groups. The total number of retrieved nodes was $20.2 \pm 7.1$ in the PFI vs. $21.51 \pm 9.2$ in the MLI group. Our results are supported by the findings of many literature publications ${ }^{(8,13,14)}$.

Orr et al. found no significant difference in the number of resected lymph nodes between the Pfannenstiel and midline groups (26.6 vs. 27.9) ${ }^{(13)}$. Scribner et al. also reported no difference with respect to the number of removed pelvic (20.8 vs. 23.1), common iliac (5.2 vs. 6.5 ), and paraaortic (6.9 vs. 6.5) lymph nodes between the MLI and PFI groups $^{(8)}$. Ayhan et al. reported no significant differences with respect to the number of resected pelvic $(23.05 \pm 9.7$ vs. $23.5 \pm 8.07, p=0.79)$ and aortic nodes $(3.17 \pm 1.68$ vs. $2.66 \pm 1.15, p=0.09$ ) between the MLI and PFI groups ${ }^{(14)}$. These findings contradict the commonly held concept that midline laparotomy is mandatory for effective lymph node sampling.
The National Comprehensive Cancer Network guidelines state that for endometrial carcinoma staging, total abdominal hysterectomy and bilateral salpingo-oophorectomy as well as lymph node assessment are the standard principles of surgical management. Omental biopsy, but not omentectomy, is recommended. Exceptions include serous and clear cell histologic types which have a more aggressive behavior and metastatic potential similar to high-grade ovarian serous tumors ${ }^{(15,16)}$. In our study, omental biopsy was done through either midline or PFI.

The limitations of our study include the retrospective design with its inherent selection and reporting bias. Furthermore, our study did not compare PF and ML incisions with laparoscopic staging for endometrial cancer.

\section{CONCLUSIONS}

In conclusion, PFI can be safely applied in selected patients of early stage endometrial carcinoma without compromising the oncologic safety. Moreover, effective pelvic and para-aortic node dissection can be achieved. Pfannenstiel incision is associated with decreased postoperative morbidity rates as well as shorter length of hospital stay. In addition, PFI provides better cosmesis and patient satisfaction.

\section{Conflict of interest}

The authors declare no competing interests.

\section{Authors' contributions}

$M J, M O$ and $M E$ designed the research study. MJ, MO, HA and AH performed the research. MR analyzed the data. MO, MR and $M J$ wrote the manuscript. All authors contributed to editorial changes in the manuscript. All authors read and approved the final manuscript.

\section{Ethics approval and consent to participate}

The study was approved by the local institutional review board (IRB). Written informed consent was obtained from all participants, keeping personal data in confidentiality.

\section{References}

1. Bray F, Ferlay J, Soerjomataram I et al.: Global cancer statistics 2018: GLOBOCAN estimates of incidence and mortality worldwide for 36 cancers in 185 countries. CA Cancer J Clin 2018; 68: 394-424.

2. Creasman WT, Mutch DE, Herzog TJ: ASTEC lymphadenectomy and radiation therapy studies: are conclusions valid? Gynecol Oncol 2010; 116: 293-294.

3. Leitao MM, Barakat RR: Advances in the management of endometrial carcinoma. Gynecol Oncol 2011; 120: 489-492.

4. Benedetti Panici P, Basile S, Maneschi F et al.: Systematic pelvic lymphadenectomy vs. no lymphadenectomy in early-stage endometrial carcinoma: randomized clinical trial. J Natl Cancer Inst 2008; 100: 1707-1716.

5. ASTEC study group; Kitchener H, Swart AMC, Qian Q et al.: Efficacy of systematic pelvic lymphadenectomy in endometrial cancer (MRC ASTEC trial): a randomised study. Lancet 2009; 373: $125-136$. 
6. Seracchioli R, Solfrini S, Mabrouk M et al.: Controversies in surgical staging of endometrial cancer. Obstet Gynecol Int 2010; 2010: 181963.

7. Dursun P, Gultekin M, Ayhan A: Performing a surgical procedure through midline incision is not a "surgical dogma" in some circumstances in gynecologic oncology. Gynecol Oncol 2003; 91: 657-658; author reply 658 .

8. Scribner DR Jr, Kamelle SA, Gould N et al.: A retrospective analysis of radical hysterectomies done for cervical cancer: is there a role for the Pfannenstiel incision? Gynecol Oncol 2001; 81: 481-484.

9. Horowitz NS, Powell MA, Drescher CW et al.: Adequate staging for uterine cancer can be performed through Pfannenstiel incisions. Gynecol Oncol 2003; 88: 404-410.

10. Grantcharov TP, Rosenberg J: Vertical compared with transverse incisions in abdominal surgery. Eur J Surg 2001; 167: 260-267.

11. Habib AS, Wahl K, Gu J et al.; Adenosine Study Group: Comparison of postoperative pain outcomes after vertical or Pfannenstiel incision for major gynecologic surgery. Curr Med Res Opin 2009; 25: 1529-1534.
12. Seiler CM, Deckert A, Diener MK et al.: Midline versus transverse incision in major abdominal surgery: a randomized, double-blind equivalence trial (POVATI: ISRCTN60734227). Ann Surg 2009; 249: 913-920.

13. Orr JW Jr, Orr PJ, Bolen DD et al.: Radical hysterectomy: does the type of incision matter? Am J Obstet Gynecol 1995; 173: 399-405; discussion 405-406.

14. Ayhan A, Dursun P, Gultekin M et al.: Pfannenstiel vs. midline incision for early stage endometrial carcinoma. Int J Gynaecol Obstet 2006; 93: 67-69.

15. Chen M, Guo P, Tan J et al.: The role of omentectomy in the surgical treatment of uterine serous carcinoma. Eur J Obstet Gynecol Reprod Biol X 2019; 4: 100084.

16. NCCN.org. NCCN Clinical Practice Guidelines in Oncology. Uterine neoplasms - Version 1.2019. 2018. 